\title{
VARIABEL PENENTU PRODUKTIVITAS AMIL DAN KINERJA PENYALURAN ZAKAT DAN INFAQ PADA BAZNAS KABUPATEN DI PROVINSI JAWA TIMUR
}

\author{
Zakiyyah Ilma Ahmad ${ }^{\mathbf{1}}$ \\ Email: zakiyyahilma@gmail.com
}

\begin{abstract}
This study aims to determine how the performance of BAZNAS Jawa Timur in zakat, infaq, and shadaqah distribution. This type of research is explanatory research, namely research that explains the relationship of the influence of independent variables on the dependent variable through the hypothesis test. Type of data used in this study is secondary data in the form of financial data sourced from financial statements related to the variables studied. Data source obtained by BAZNAS financial report in East Java Province. The results of this study are the zakat collection variable and infaq collection variable does not affect the amil productivity. Amil productivity does not affect the performance of zakat distribution and infaq distribution performance. All hypotheses are rejected
\end{abstract}

Keywords: Zakat, Infaq, Shadaqah, Collecting, Amil Productivity, Distribution Performance.

\section{PENDAHULUAN}

Zakat dan Infaq merupakan salah satu upaya yang dapat memberikan kontribusi positif bagi masyarakat maupun negara. Bagi negara, zakat, dan infaq dapat membantu terciptanya pemerataan pendapatan yang lebih baik. Pemerataan pendapatan di Indonesia merupakan hal yang memiliki perhatian khusus bagi pemerintah. Masih tingginya tingkat ketimpangan pendapatan membuat sebagian masyarakat Indonesia masih belum dapat merasa kesejahteraan secara utuh. Selain itu, masih tingginya tingkat ketimpangan pendapatan juga menyebabkan peningkatan jumlah dua golongan, yaitu golongan orang yang dapat memenuhi kebutuhannya secara mudah (golongan kaya) dan golongan orang yang sulit memenuhi kebutuhan hidupnya (golongan fakir dan miskin). Berdasarkan data Badan Pusat Statistik (BPS) Maret 2017, jumlah penduduk miskin (penduduk dengan pengeluaran per kapita per bulan di bawah Garis Kemiskinan) di Indonesia mencapai 27,77 juta orang (10,64 persen), bertambah sebesar 6,90 ribu orang dibandingkan dengan kondisi September 2016 yang sebesar 27,76 juta orang (10,70 persen).

Salah datu upaya untuk mengurangi jumlah kemiskinan tersebut adalah pemerintah telah mengeluarkan peraturan atau undang-undang yang mengatakan

${ }^{1}$ Corresponding author: Institut Agama Islam Negeri Jember. Jl. Mataram No.1, Karang Miuwo, Mangli, East Java, Kabupaten Jember, Jawa Timur 68136 
tentang hal tersebut, yaitu (UU Nomor 23 Tahun 2011 tentang Pengelolaan Zakat) yang di dalamnya juga membahas tentang infaq. Undang-Undang tersebut menjelaskan secara lengkap dan jelas bagaimana sikap yang seharusnya dilakukan oleh Organisasi Pengelola Zakat (OPZ). Di samping pemerintah mengeluarkan Undang-Undang tersebut, Ikatan Akuntan Indonesia (IAI) juga telah mengeluarkan peraturan mengenai infaq, yang diatur di dalam PSAK 109 tentang Akuntansi Zakat, Infaq, dan Sedekah.

Baznas merupakan lembaga yang berwenang melakukan tugas pengelolaan zakat secara nasional. Baznas bukan lembaga perseorangan melainkan badan atau lembaga. Lembaga Baznas ini mempunyai amanah dalam mewujudkan tujuan zakat. Baznas juga mempunyai fungsi yaitu tentang perencanaan, pelaksanaan, pengendalian, pelaporan, dan pertanggungjawaban atas pengumpulan, pendistribusian dan pendayagunaan zakat. Kewajiban Baznas melaksanakan fungsi tersebut dan menerapkan kaidah-kaidah manajemen yang efektif dan efisien sehingga terwujud dengan baik apa yang diinginkan oleh lembaga pengelola zakat. Peran dan kontribusi Baznas kepada masyarakat, terutama peran dari Baznas dalam menyebarluaskan nilai-nilai zakat di tengah masyarakat. Yakni dengan memberikan nilai-nilai keimanan dan ketakwaan kepada Allah SWT, etos kerja, etika kerja dalam mencari rezeki yang halal dan baik, serta nilai-nilai zakat yang berkenaan dengan pembangunan karakter manusia (character building) sebagai insan yang saling memberi manfaat bagi sesama.

Ketua Baznas Jatim Abdussalam Nawawi mengatakan, pada 2016 dana yang terhimpun di Baznas provinsi dan 38 kabupaten/kota mencapai Rp 42,7 miliar. Angka tersebut naik 25\% dibandingkan dana yang terhimpun pada 2015 senilai 32 miliar. Amil bertugas menghimpun dana zakat baik individu (berupa zakat profesi, zakat hasil panen dll) maupun dari organisasi (misalnya zakat keuntungan perusahaan). Dalam menjalankan tugasnya, amil zakat dalam hal ini adalah para pengurus dan karyawan BAZNAS berhak mendapatkan hak amil sebesar 12,5\% dari jumlah zakat yang dihimpun. Semakin besar dana zakat yang dihimpun maka semakin besar pula dana amil. Dana amil yang berasal dari $12,5 \%$ dari jumlah zakat dipakai oleh amil untuk mengelola zakat tersebut melalui penyaluran zakat sehingga dengan tugas tersebut dibutuhkan dana untuk membiayai operasional amil. Sehingga semakin besar dana zakat sangat mempengaruhi produktivitas amil. Amil bertugas menghimpun dana infaq/shodaqah baik individu maupun dari organisasi /perusahaan.

Dalam menjalankan tugasnya, amil zakat dalam hal ini adalah para pengurus dan karyawan BAZNAS berhak mendapatkan hak amil biasanya sebesar $20 \%$ dari jumlah infaq/shodaqah yang dihimpun. Semakin besar dana infaq yang dihimpun maka semakin besar pula dana amil. Dana amil yang berasal dari $20 \%$ dari jumlah infaq/shodaqah dipakai oleh amil untuk mengelola infaq/shodaqah tersebut melalui penyaluran infaq/shodaqah sehingga dengan tugas tersebut dibutuhkan dana untuk membiayai operasional amil. Sehingga semakin besar dana infaq/shodaqah sangat mempengaruhi produktivitas amil.

Amil bertugas menyalurkan dana zakat kepada mustahik melalui kegiatan konsumtif, edukatif dan produktif. Beberapa organisasi pengelola zakat mampu menghimpun dana zakat dalam jumlah besar namun kurang mampu dalam menyalurkan dana zakat. Disisi lain, ada organisasi pengelola zakat kurang mampu menghimpun dana zakat dalam jumlah besar namun sangat mampu dalam menyalurkan dana zakat. Dibutuhkan manajemen Badan Amil Zakat yang kompeten, 
profesional sehingga mendorong produktivitas para pengurus dan karyawan mampu menghimpun dana zakat dalam jumlah besar sekaligus mampu dalam menyalurkan dana zakat. Sehingga semakin produktif amil zakat maka semakin baik kinerja penyaluran zakat.

Amil bertugas menyalurkan dana infaq/shodaqah kepada para dhuafa dan pihak yang sangat membutuhkan pertolongan melalui kegiatan konsumtif, edukatif dan produktif. Beberapa organisasi pengelola infaq/shodaqah mampu menghimpun dana infaq/shodaqah dalam jumlah besar namun kurang mampu dalam menyalurkan dana infaq/shodaqah. Disisi lain, ada organisasi pengelola infaq/shodaqah kurang mampu menghimpun dana infaq/shodaqah dalam jumlah besar namun sangat mampu dalam menyalurkan dana infaq/shodaqah Dibutuhkan manajemen Badan Amil Zakat yang kompeten, profesional sehingga mendorong produktivitas para pengurus dan karyawan mampu menghimpun dana infaq/shodaqah dalam jumlah besar sekaligus mampu dalam menyalurkan dana infaq/shodaqah. Sehingga semakin produktif amil maka semakin baik kinerja penyaluran infaq/shodaqah.

Berdasarkan latar belakang permasalahan yang telah diuraikan sebelumnya, maka dapat dirumuskan pokok permasalahan sebagai berikut:

1. Apakah penghimpunan zakat berpengaruh terhadap produktivitas amil?

2. Apakah penghimpunan infaq berpengaruh terhadap produktivitas amil?

3. Apakah produktivitas amil berpengaruh terhadap kinerja penyaluran zakat?

4. Apakah produktivitas amil berpengaruh terhadap kinerja penyaluran infaq?

\section{TINJAUAN PUSTAKA}

\subsection{Teori Enterprise Syariah}

Teori enterprise syariah menyeimbangkan nilai egoistik dengan nilai altruistik, nilai materi dengan nilai spiritual dan nilai individu dengan jama'ah. Dalam syariah Islam, bentuk keseimbangan tersebut secara konkret diwujudkan dalam salah satu bentuk ibadah, yaitu zakat (Triyuwono 2006). Konsekuensi dari nilai keseimbangan ini menyebabkan teori enterprise syariah tidak hanya peduli pada kepentingan individu (dalam hal ini pemegang saham), tetapi juga pihak-pihak lainnya. Teori enterprise syariah memiliki cakupan akuntabilitas yang lebih luas dibandingkan dengan teori entitas. Akuntabilitas yang dimaksud adalah akuntabilitas kepada Tuhan, manusia, dan alam (Triyuwono 2006)

Teori enterprise syariah mengfungsikan agama (syariah) sebagai suatu hal yang menyatakan dalam agency theory, maka memunculkan batasan perilaku berupa kode etik bagi pihak-pihak yang terlibat dalam dimensi hubungan kontrak antara prinsipal dan agen seperti halnya antara bank Islam dengan mudharib dalam pembiayaan mudharabah. Jika pihak-pihak yang terlibat dalam transaksi (kontrak) bisnis seperti kontrak mudharabah memiliki keyakinan kehidupan akhirat yang abadi dan sejahtera maka mempengaruhi perilaku pihak-pihak yang terlibat untuk selaku bertindak (beretika) secara Islami dan menghindari tindakan yang merugikan satu sama lain.

\subsection{Teori Akuntansi Syariah}

Akuntansi syariah didefinisikan sebagai proses akuntansi yang menyediakan informasi yang tepat/sesuai (yang tidak dibatasi pada data keuangan) kepada stakeholders dari suatu entitas yang memungkinkan mereka untuk menyakinkan bahwa entitas beroperasi secara kontinyu dalam ikatan syariah Islam dan 
mengantarkan pada tujuan falah, yaitu mencapai kebahagiaan dunia-akhirat, kesejahteraan materi-spiritual. Menurut Hayashi, dalam akuntansi syariah ada meta rule yang berasal di luar konsep akuntansi yang harus dipatuhi, yaitu hukum syariah yang berasal dari Tuhan yang bukan ciptaan manusia, dan akuntansi syariah sesuai dengan kecenderungan manusia yaitu hanief yang menuntut agar perusahaan juga memiliki etika dan tanggung jawab sosial, bahkan ada pertanggungjawaban di akhirat, di mana setiap orang mempertanggungjawabkan tindakannya di hadapan Tuhan yang memiliki akuntan sendiri (malaikat Rakib dan Atid) yang mencatat semua tindakan manusia bukan saja pada bidang ekonomi, tetapi juga masalah sosial dan pelaksanaan hukum syariah lainnya (Harahap 1997; Gamal 2007). Akuntansi harus dianggap sebagai salah satu derivasi (hisab) yaitu menganjurkan yang baik dan melarang apa yang jelek.

Menurut Triyuwono (2006) teori akuntansi syariah dikembangkan dengan menginternalisasikan nilai Islam ke dalam teori enterprise. Pengembangan akuntansi syariah salah satunya adalah digunakannya teori enterprise syariah dalam menjustifikasi akuntansi syariah. Akuntansi syariah bukan saja untuk melayani kepentingan stockholder, tapi juga semua pihak yang terlibat atau stakeholder. Itu berarti ada upaya melindungi kepentingan masyarakat yang terkait langsung maupun tidak langsung. Bahkan dunia flora- fauna berikut lingkungan yang menjadi habitatnya. Karena itu akuntansi Islam bukan melulu bicara angka. Sebaliknya, domain akuntansi syariah juga mengukur perilaku (behaviour). Konsekuensinya akuntansi syariah menjadi mizan dalam penegakan ketertiban perdagangan, pembagian yang adil, pelarangan penipuan mutu, timbangan, bahkan termasuk mengawasi agar tidak terjadi benturan kepentingan antara perusahaan yang bisa merugikan kalangan lain (Triyuwono 2006).

\subsection{BAZNAS (Badan Amil Zakat Nasional)}

Badan Amil Zakat Nasional (BAZNAS) merupakan badan resmi dan satusatunya yang dibentuk oleh pemerintah berdasarkan (Keputusan Presiden RI No. 8 Tahun 2001 tentang Badan Amil Zakat Nasional) yang memiliki tugas dan fungsi menghimpun dan menyalurkan zakat, infaq, dan sedekah (ZIS) pada tingkat nasional. Lahirnya (Undang-Undang Nomor 23 Tahun 2011 tentang Pengelolaan Zakat) semakin mengukuhkan peran BAZNAS sebagai lembaga yang berwenang melakukan pengelolaan zakat secara nasional. Dalam UU tersebut, BAZNAS dinyatakan sebagai lembaga pemerintah non-struktural yang bersifat mandiri dan bertanggung jawab kepada Presiden melalui Menteri Agama. Dengan demikian, BAZNAS bersama Pemerintah bertanggung jawab untuk mengawal pengelolaan zakat yang berasaskan: syariat Islam, amanah, kemanfaatan, keadilan, kepastian hukum, terintegrasi dan akuntabilitas.

\subsection{Zakat}

Menurut PSAK NO. 109, pengertian zakat adalah harta yang wajib dikeluarkan oleh muzzaki sesuai dengan ketentuan syariah untuk diberikan kepada yang berhak menerimanya (mustahiq). Zakat diyakini merupakan ibadah yang berperan strategis dalam mendorong pemerataan kemakmuran masyarakat suatu negara. Zakat dapat memberikan jaminan sosial bagi masyarakat yang membutuhkan kedermawanan secara finansial. Dalam hal ini masyarakat yang dimaksud adalah yang memenuhi kriteria sebagai penerima (mustahiq). Zakat 
merupakan bagian dari kedermawanan (filantropi) dalam konteks masyarakat muslim. Zakat adalah salah satu dari lima Rukun Islam yang wajib dilaksanakan. Dalam Al-Qur'an, tidak kurang dari 28 ayat Allah Swt., menyebutkan perintah zakat, di antaranya adalah surat Al-Baqoroh ayat 43, yang artinya Dirikanlah shalat, tunaikanlah zakat, serta ruku'lah bersama orang-orang yang ruku (Departemen Zakat adalah istilah Al-Quran yang menandakan kewajiban khusus memberikan sebagian kekayaan individu dan harta untuk amal.

Secara harfiah zakat berasal dari akar kata dalam bahasa arab yang berarti memurnikan dan menumbuhkan (Manan 1986). Secara estimologis zakat juga berarti membersihkan dan menyucikan, yang berarti membersihkan diri yang didapatkan setelah pelaksanaan kewajiban zakat (Mardani 2015). Menurut Yusuf Al-Qardawi dalam Nurul Huda, dkk., menurut lisanul arab arti dasar dari kata zakat ditinjau dari sudut bahasa adalah suci, tumbuh, berkah dan terpuji, semuanya digunakan dalam Al-Qur'an dan hadist. Zakat dalam Al-Qur'an juga disebutkah dengan kata shadaqah, sehingga mawardi mengatakan bahwa shadaqah itu adalah zakat dan zakat adalah shadaqah, berbeda nama tetapi arti sama.

\subsection{Infaq}

Secara bahasa, infaq berasal dari kata anfaqa yang berarti mengeluarkan sesuatu untuk kepentingan sesuatu. Sementara menurut istilah syari'at, infaq berarti mengeluarkan sebagian dari harta atau pendapatan/penghasilan untuk suatu kepentingan yang diperintahkan agama Islam. Menurut (Undang-Undang Nomor 23 Tahun 2011 tentang Pengelolaan Zakat), infaq adalah harta yang dikeluarkan oleh seseorang atau badan usaha di luar zakat untuk kemaslahatan umum. Dari beberapa pengertian tersebut, dapat disimpulkan bahwa infaq berarti mengeluarkan harta yang dimiliki oleh seseorang atau badan yang digunakan untuk kepentingan umum yang diperintahkan dalam agama Islam.

\subsection{Jenis-Jenis Infaq}

Menurut Nurhayati dan Wasilah (2015) infaq dibedakan menjadi dua, yaitu sebagai berikut:

1. Infaq Wajib: terdiri atas zakat dan nazar, yang bentuk dan jumlah pemberiannya telah ditentukan. Nazar adalah sumpah atau janji untuk melakukan sesuatu di masa yang datang. Seseorang yang bernazar: jika saya lulus ujian, maka saya memberikan Rp. 500.000 kepada fakir miskin, wajib melaksanakan nazarnya seperti yang telah dia ucapkan. Jika hal tersebut tidak dilakukan, maka dia terkena denda/kafarat.

2. Infaq Sunah: infaq yang dilakukan seorang muslim untuk mencari rida Allah, bisa dilakukan dengan berbagai cara dan bentuk. Misalnya: memberi makanan bagi orang terkena bencana.

\subsection{Produktivitas}

Ukuran kinerja lainnya ialah produktivitas. Produktivitas adalah perbandingan antara nilai barang yang dihasilkan dari suatu aktivitas produksi dengan biaya-biaya yang dikeluarkan untuk menghasilkan barang tersebut dalam suatu periode tertentu. Terdapat tiga hal penting yang harus diketahui dari pengukuran produktivitas, yaitu: Pertama, pengukuran produktivitas berdampak pada neraca. Kedua, pengukuran produktivitas berdampak pada laporan laba-rugi. 
Aliran bahan baku yang kemudian diproses dalam proses produksi berdampak pada kedua hal tersebut di atas. Ketiga, pengukuran produktivitas haruslah memungkinkan untuk diterapkan serta fleksibel terhadap perubahan salah satu variabel. Pengukuran produktivitas seharusnya dapat mencerminkan kondisi perusahaan di masa yang datang di mana hal ini tidak dapat diketahui dari laporan neraca dan laba-rugi. Laba yang dicapai oleh perusahaan mungkin tinggi dan modal yang digunakan berada pada kondisi yang baik, tetapi apabila tidak disertai peningkatan produktivitas maka perusahaan tidak bisa bertahan dalam jangka panjang. Pengukuran produktivitas yang dilakukan oleh perusahaan mencerminkan peningkatan aktivitas operasional perusahaan terlepas dari kondisi perekonomian secara makro.

\subsection{Kinerja}

Pengukuran kinerja keuangan lembaga zakat yang tercantum dalam International Standard of Zakat Management (ISZM) terdiri atas pengukuran terhadap efisiensi lembaga zakat dan pengukuran terhadap kapasitas organisasi. Pengukuran komponen efisiensi ini memperlihatkan apakah pengelolaan dana yang dilakukan lembaga zakat sudah efisien atau belum.

Pengelolaan lembaga memerlukan tata kelola korporasi yang baik (Kustono dan Effendi 2016). Tata kelola yang baik akan menjaga kinerja lembaga tetap optimal dan mencapai nilai-nilai 3E. Nilai itu adalah efisiensi, efektivitas, dan ekonomis. Lembaga zakat yang dikatakan efisien apabila mengeluarkan sedikit biaya untuk mendapatkan penghimpunan dana di mana usaha penghimpunan ini harus sejalan dengan program dan pelayanan lembaga zakat. Berdasarkan hal tersebut maka pengeluaran yang dilakukan lembaga zakat harus lebih banyak digunakan untuk program dan pelayanannya.

Efisiensi pengelolaan zakat dapat diukur dengan rasio beban program, rasio beban operasional, rasio beban penghimpunan dan efisiensi penghimpunan. Rasio beban program didapat dengan membagi total biaya program dengan total biaya yang dikeluarkan lembaga zakat selama satu tahun. Biaya program yang dimaksudkan adalah pengeluaran yang ditujukan untuk pemberdayaan mustahik. Sehingga terlihat perbandingan besar pengeluaran untuk menjalankan program dengan total seluruh pengeluaran. Semakin besar hasilnya maka semakin baik. Beban operasional adalah pengeluaran lembaga zakat untuk kegiatan operasional, yang mana hal ini tercermin dalam penggunaan dana amil. Rasio ini didapat dengan membandingkan total pengeluaran untuk operasional dengan keseluruhan pengeluaran. Maka diketahui besaran komposisi beban operasional dari total pengeluaran. Berapa banyak yang dikeluarkan lembaga zakat untuk operasionalnya. Jika hasilnya terlalu besar dari total keseluruhan pengeluaran maka dapat disimpulkan bahwa lembaga zakat belum efisien dalam mengelola beban operasionalnya. Seharusnya pengeluaran lembaga zakat lebih fokus kepada program-program dan pelayanan untuk mustahik.

Beban penghimpunan dalam lembaga zakat adalah biaya-biaya yang dikeluarkan dalam rangka penghimpunan dana, seperti biaya iklan, sosialisasi dll. Rasio beban penghimpunan didapat dengan membagi total beban penghimpunan dengan keseluruhan beban atau pengeluaran lembaga zakat. Apabila beban penghimpunan dana ini lebih besar dari pada penghimpunan dana yang didapat oleh lembaga zakat maka perlu dipertanyakan bagaimana kinerja lembaga tersebut dalam 
mengelola keuangannya. Rasio efisiensi penghimpunan didapat dengan membagi total biaya yang dikeluarkan untuk menghimpun dana dengan total kontribusi yang diberikan oleh muzakki atau penghimpunan dana dari muzakki. Maka berdasarkan hal tersebut dapat diketahui berapa banyak yang dikeluarkan oleh lembaga zakat untuk menghasilkan setiap 1 rupiah penghimpunan. semakin baik apabila jumlah dana yang dikeluarkan oleh lembaga zakat untuk menghasilkan setiap 1 rupiah kontribusi nilainya rendah, sehingga mencerminkan bahwa lembaga zakat tersebut telah efisien.

\subsection{Pengembangan Hipotesis}

\subsubsection{Hubungan Pengaruh Penghimpunan Zakat Terhadap Produktivitas Amil}

Amil bertugas menghimpun dana zakat baik individu (berupa zakat profesi, zakat hasil panen dll.) maupun dari organisasi (misalnya zakat keuntungan perusahaan). Dalam menjalankan tugasnya, amil zakat dalam hal ini adalah para pengurus dan karyawan BAZNAS berhak mendapatkan hak amil sebesar 12,5\% dari jumlah zakat yang dihimpun. Semakin besar dana zakat yang dihimpun maka semakin besar pula dana amil. Dana amil yang berasal dari 12,5\% dari jumlah zakat dipakai oleh amil untuk mengelola zakat tersebut melalui penyaluran zakat sehingga dengan tugas tersebut dibutuhkan dana untuk membiayai operasional amil. Sehingga semakin besar dana zakat sangat mempengaruhi produktivitas amil. Berdasarkan paparan tersebut, maka dapat dirumuskan hipotesis sebagai berikut.

H1: penghimpunan zakat berpengaruh terhadap produktivitas amil;

\subsubsection{Hubungan Pengaruh Penghimpunan Infaq Terhadap Produktivitas Amil}

Amil bertugas menghimpun dana infaq/shodaqah baik individu maupun dari organisasi /perusahaan. Dalam menjalankan tugasnya, amil zakat dalam hal ini adalah para pengurus dan karyawan BAZNAS berhak mendapatkan hak amil biasanya sebesar $20 \%$ dari jumlah infaq/shodaqah yang dihimpun. Semakin besar dana infaq yang dihimpun maka semakin besar pula dana amil. Dana amil yang berasal dari $20 \%$ dari jumlah infaq/shodaqah dipakai oleh amil untuk mengelola infaq/shodaqah tersebut melalui penyaluran infaq/shodaqah sehingga dengan tugas tersebut dibutuhkan dana untuk membiayai operasional amil. Sehingga semakin besar dana infaq/shodaqah sangat mempengaruhi produktivitas amil. Putri (2017) meneliti tentang analisis kinerja pengelolaan zakat di Badan Amil Zakat Nasional (BAZNAS) Kota Yogyakarta. Hasilnya menunjukkan Nilai IZN BAZNAS Kota Yogyakarta adalah 0.4338 menunjukkan bahwa kinerja BAZNAS sudah cukup baik Nilai indeks pada dimensi mikro yaitu 0.69 dan termasuk dalam kategori kinerja baik. Berdasarkan paparan tersebut, maka dapat dirumuskan hipotesis sebagai berikut.

H2: penghimpunan infaq berpengaruh terhadap produktivitas amil;

\subsection{Hubungan Pengaruh Produktivitas Amil Terhadap Kinerja Penyaluran Zakat}

Amil bertugas menyalurkan dana zakat kepada mustahik melalui kegiatan konsumtif, edukatif dan produktif. Beberapa organisasi pengelola zakat mampu menghimpun dana zakat dalam jumlah besar namun kurang mampu dalam 
menyalurkan dana zakat. Disisi lain, ada organisasi pengelola zakat kurang mampu menghimpun dana zakat dalam jumlah besar namun sangat mampu dalam menyalurkan dana zakat. Dibutuhkan manajemen Badan Amil Zakat yang kompeten, profesional sehingga mendorong produktivitas para pengurus dan karyawan mampu menghimpun dana zakat dalam jumlah besar sekaligus mampu dalam menyalurkan dana zakat. Sehingga semakin produktif amil zakat maka semakin baik kinerja penyaluran zakat.

Devi (2018) meneliti pengaruh profesionalisme, job stress, dan perilaku etis terhadap kinerja karyawan pada Badan Amil Zakat Nasional (BAZNAS) di Jawa Timur. Hasilnya menunjukkan variabel bebas profesionalisme berpengaruh terhadap kinerja karyawan, job stress berpengaruh terhadap kineja karyawan perilaku etis berpengaruh terhadap kinerja karyawan pada BAZNAS di Jawa Timur.

Lestari (2015) melakukan penelitian mengenai efisiensi kinerja Keuangan Badan Amil Zakat Daerah (BAZDA): Pendekatan Data Envelopment Analysis (DEA) menunjukkan bahwa BAZDA telah mampu mencapai nilai aktual (nilai sebenarnya) sesuai dengan nilai target (nilai yang harus dicapai) yang disarankan oleh DEA. BAZDA telah mampu mencapai efisiensi maksimum secara relatif.

Parisi (2017) menguji tingkat efisiensi dan produktivitas lembaga zakat di Indonesia menyatakan faktor utama inefisiensi organisasi pengelola zakat (dalam pengamatan) dari tahun 2005 hingga 2014 disebabkan oleh penyaluran dana zakat terhadap ashnaf yang masih kurang optimal. Zakat belum mampu menyelesaikan problematika kemiskinan. Berdasarkan paparan tersebut, maka dapat dirumuskan hipotesis sebagai berikut.

H3: produktivitas amil berpengaruh terhadap kinerja penyaluran zakat;

\subsubsection{Hubungan Pengaruh Produktivitas Amil Terhadap Kinerja Penyaluran Infaq}

Amil bertugas menyalurkan dana infaq/shodaqah kepada para dhuafa dan pihak yang sangat membutuhkan pertolongan melalui kegiatan konsumtif, edukatif dan produktif. Beberapa organisasi pengelola infaq/shodaqah mampu menghimpun dana infaq/shodaqah dalam jumlah besar namun kurang mampu dalam menyalurkan dana infaq/shodaqah. Disisi lain, ada organisasi pengelola infaq/shodaqah kurang mampu menghimpun dana infaq/shodaqah dalam jumlah besar namun sangat mampu dalam menyalurkan dana infaq/shodaqah Dibutuhkan manajemen Badan Amil Zakat yang kompeten, profesional sehingga mendorong produktivitas para pengurus dan karyawan mampu menghimpun dana infaq/shodaqah dalam jumlah besar sekaligus mampu dalam menyalurkan dana infaq/shodaqah. Sehingga semakin produktif amil maka semakin baik kinerja penyaluran infaq/shodaqah.

Sasongko (2018) meneliti mengenai Analisis Efisiensi dan Efektivitas Kinerja Pengelolaan Dana Zakat, Infaq, Shodaqoh di Organisasi Pengelola Zakat Jawa Timur. Hasilnya menunjukkan BAZNAS Jatim dapat diketahui sepanjang 20142016, telah melakukan pengelolaan zakat cukup efektif denga rata- rata tingkat keefektivan sebesar $74 \%$. Untuk tingkat efektivitas infaq shodaqoh denga rata - rata tingka keefektifan sebsesar $92 \%$.

Azizah (2018) meneliti efektivitas kinerja keuangan Badan Amil Zakat (BAZNAS) dalam proses distribusi dana zakat, yaitu Jogja Taqwa, Jogja Peduli, Jogja Sehat, Jogja Cerdas, Jogja Sejahtera dari 2012-2016. Penelitian ini yang dilakukan di BAZNAS Yogyakarta, secara khusus menganalisis distribusi dana zakat 
menggunakan Alokasi untuk metode analisis Collection Ratio (ACR). Hasil penelitiannya menunjukkan tingkat efektivitas distribusi zakat setiap tahun, tahun 2012 menunjukkan cukup efektif skor, tahun 2013 berada pada level efektif, tahun 2014 menunjukkan skor efektif, yaitu tingkat skor 2015 adalah sangat efektif dan analisis menunjukkan cukup efektif skor pada tahun 2016. Berdasarkan paparan tersebut, maka dapat dirumuskan hipotesis sebagai berikut.

H4: produktivitas amil berpengaruh terhadap kinerja penyaluran infaq.

\section{METODE PENELITIAN}

\subsection{Jenis Penelitian}

Jenis penelitian ini adalah explanatory research yaitu penelitian yang menjelaskan hubungan pengaruh variabel independen terhadap variabel dependen melalui uji hipotesis.

\subsection{Jenis dan Sumber Data}

Jenis data yang digunakan dalam penelitian ini adalah data sekunder yang berupa data keuangan yang bersumber dari laporan keuangan yang terkait dengan variabel yang diteliti. Sumber data diperoleh laporan keuangan BAZNAS Kabupaten di Jawa Timur.

\subsection{Teknik Pengumpulan Data}

Teknik pengumpulan data yang digunakan dalam penelitian ini adalah dokumentasi yang merupakan teknik pengumpulan data penelitian dengan cara menggali data sekunder yang bersumber dari dokumen dan laporan. Dokumen/laporan yang dibutuhkan dalam penelitian ini adalah laporan keuangan yang di publikasi melalui website Badan Amal Zakat di Jawa Timur.

\subsection{Populasi dan Sampel}

Populasi adalah wilayah himpunan semesta yang terdiri atas subyek dan obyek dengan kualitas/karakteristik yang ditentukan oleh peneliti untuk dipelajari dan dapat disimpulkan dari peneliti tersebut. Sampel adalah sebagian dari anggota populasi yang diambil menurut prosedur tertentu sehingga diharapkan dapat mewakili populasinya.

\subsection{Variabel Penelitian}

Sugiyono (2016) mengatakan bahwa variabel adalah suatu atribut atau sifat atau nilai dari orang, obyek atau kegiatan yang mempunyai variasi tertentu yang ditetapkan oleh peneliti untuk dipelajari dan kemudian ditarik kesimpulannya. Penelitian ini mencoba untuk menganalisis variabel penentu produktivitas amil dan kinerja penyaluran zakat dan infaq di BAZNAS kabupaten di Provinsi Jawa Timur.

\section{a. Variabel Endogen}

Menurut Sugiyono (2016), variabel endogen disebut juga dengan variabel dependen (terikat), yaitu variabel yang dipengaruhi atau yang menjadi akibat, karena adanya variabel bebas. Variabel endogen dalam penelitian adalah produktivitas amil, kinerja penyaluran zakat dan kinerja penyaluran infaq. Variabel produktivitas amil diukur dengan jumlah pengeluaran amil dibagi dengan jumlah penerimaan dana amil. Variabel 
kinerja penyaluran zakat diukur dengan jumlah penyaluran zakat dibagi dengan jumlah penerimaan zakat. Sedangkan kinerja penyaluran infaq diukur dengan jumlah penyaluran infaq dibagi dengan jumlah penerimaan infaq.

\section{b. Variabel Eksogen}

Menurut Sugiyono (2016), variabel eksogen disebut juga dengan variabel independen (bebas), yaitu variabel yang mempengaruhi atau yang menjadi sebab perubahannya atau timbulnya variabel dependen (terikat). Variabel eksogen dalam penelitian ini adalah penghimpunan zakat dan penghimpunan infaq. Variabel penghimpunan zakat diukur dengan banyaknya jumlah zakat yang dihimpun. Sedangkan variabel penghimpunan infaq diukur dengan banyaknya jumlah infaq yang dihimpun.

\subsection{Teknik Analisis Data}

Teknik analisis data dalam penelitian ini adalah analisis jalur digunakan untuk pengujian hipotesis dengan menggun Partial Least Squares (PLS). Menurut Ghozali dan Latan (2015), PLS merupakan metode analisis yang powerful oleh karena tidak didasarkan banyak asumsi. Data tidak harus berdistribusi normal multivariate, sampel tidak harus besar dan residual distribution.

\section{HASIL DAN PEMBAHASAN}

\subsection{Sampel Penelitian}

Populasi dalam penelitian ini adalah BAZNAS Kabupaten di Jawa Timur. Sedangkan sampel dalam penelitian adalah BAZNAS Kabupaten di Jawa Timur yang menyusun laporan keuangan dan mempublikasikan di website BAZNAS. Teknik sampling dalam penelitian ini adalah BAZNAS Kabupaten di Jawa Timur yang menyusun laporan keuangan yang sesuai dengan PSAK 109 dan mempublikasikan di website BAZNAS di Jawa Timur. Penelitian ini menggunakan sampel jenuh. Seluruh anggota populasi menjadi sampel penelitian. Jumlah keseluruhan adalah 36 Baznas kabupaten di provinsi Jawa Timur.

\subsection{Hasil Penelitian}

Berikut ini adalah hasil data statistik yang menggunakan Partial Least Square dengan pertimbangan karena data sampel dalam jumlah kecil atau terbatas sementara teori yang melandasi hubungan antar variabel belum mapan.

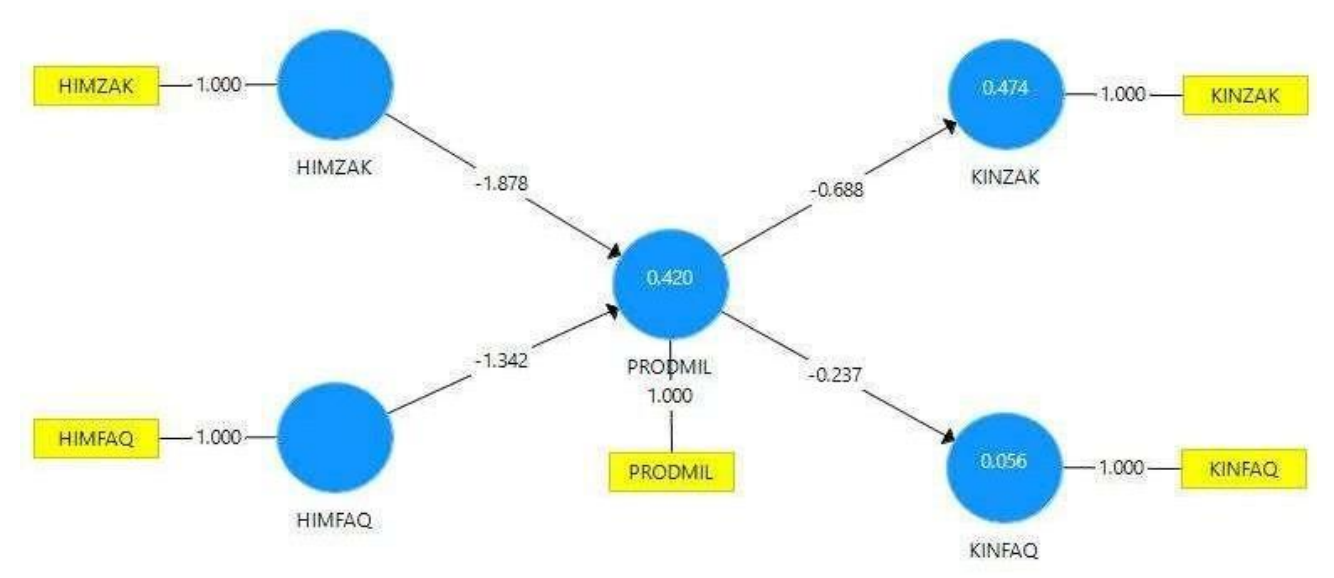




\subsection{Uji Validitas Diskriminan}

Berikut ini hasil uji validitas diskriminan seperti pada tabel di bawah ini.

Tabel 2. Hasil Uji Validitas Diskriminan

\begin{tabular}{|c|c|c|c|c|c|}
\hline & HIMFAQ & HIMZAK & KINFAQ & KINZAK & PRODMIL \\
\hline HIMFAQ & 1 & & & & \\
\hline HIMZAK & $-0,974$ & 1 & & & \\
\hline KINFAQ & 0,217 & $-0,011$ & 1 & & \\
\hline KINZAK & 0,025 & 0,073 & 0,561 & 1 & \\
\hline PRODMIL & 0,487 & $-0,571$ & $-0,237$ & $-0,688$ & 1 \\
\hline
\end{tabular}

Sumber: diolah, 2020

Selanjutnya menurut perhitungan cross loading (discriminant validity) di atas dapat disimpulkan semua variabel memiliki korelasi tertinggi pada dirinya sendiri (yakni 1) dibandingkan dengan korelasi pada variabel lain. Dengan demikian, syarat validitas diskriminan pada kasus penelitian ini terpenuhi.

\subsection{Uji Reliabilitas dan Validitas Konstruks}

Berikut ini hasil uji reliabilitas dan validitas seperti pada tabel di bawah ini

Tabel 3 Hasil Uji Reliabilitas dan Validitas Konstruk

\begin{tabular}{ccc}
\hline & Cronbach's Alpha & Composite Reliability \\
\hline HIMFAQ & 1 & 1 \\
HIMZAK & 1 & 1 \\
KINFAQ & 1 & 1 \\
KINZAK & 1 & 1 \\
PRODMIL & 1 & 1 \\
\hline
\end{tabular}

Sumber: diolah, 2020

Berdasarkan nilai Cronbach's Alpha dan Composite Reliability yang mengukur reliabilitas model pengukuran didapatkan hasil yang bagus, yakni lebih dari rule of thumb 0,60 (Werts et al., 1974 dikutip dari Salisbury et al. 2002). Dengan demikian dapat disimpulkan bahwa model pengukuran semua variabel memiliki reliabilitas yang baik.

\subsection{Uji Hipotesis}

Berikut ini hasil uji hipotesis seperti pada tabel di bawah ini.

Tabel 4. Hasil Uji Hipotesis

\begin{tabular}{ccc}
\hline Hubungan Variabel & P- Values & Kesimpulan \\
\hline HIMFAQ $\longrightarrow$ PRODMIL & 0,542 & Tidak Signifikan \\
HIMZAK $\longrightarrow$ PRODMIL & 0,352 & Tidak Signifikan \\
PRODMIL $\longrightarrow$ KINFAQ & 0,491 & Tidak Signifikan \\
PRODMIL $\longrightarrow$ KINZAK & 0,183 & Tidak Signifikan \\
\hline
\end{tabular}

Sumber: diolah, 2020 
Rule of thumb dari terdukungnya suatu hipotesis penelitian adalah: (1) jika koefisien atau arah hubungan variabel (ditunjukkan oleh nilai original sample) sejalan dengan yang dihipotesiskan, dan (2) jika nilai t statistik lebih dari 1,64 (twotiled) atau 1,96 (one-tiled) dan probability value ( $p$-value) kurang dari 0,05 atau 5\%. Pada kasus ini, mengacu pada hasil yang disajikan pada menu Path Coefficients, semua hipotesis tidak ada yang terdukung karena nilai signifikansinya di atas 0,05 .

\subsection{Pembahasan}

\subsubsection{Pengaruh Penghimpunan Zakat Terhadap Produktivitas Amil}

Amil bertugas menghimpun dana zakat baik individu (berupa zakat profesi, zakat hasil panen dll.) maupun dari organisasi (misalnya zakat keuntungan perusahaan). Dalam menjalankan tugasnya, amil zakat dalam hal ini adalah para pengurus dan karyawan BAZNAS berhak mendapatkan hak amil sebesar 12,5\% dari jumlah zakat yang dihimpun. Semakin besar dana zakat yang dihimpun maka semakin besar pula dana amil. Dana amil yang berasal dari 12,5\% dari jumlah zakat dipakai oleh amil untuk mengelola zakat tersebut melalui penyaluran zakat sehingga dengan tugas tersebut dibutuhkan dana untuk membiayai operasional amil. Sehingga semakin besar dana zakat sangat mempengaruhi produktivitas amil. Namun berdasarkan hasil uji hipotesis statistik menunjukkan bahwa p-value pengaruh variabel penghimpunan zakat terhadap produktivitas amil sebesar 0,542 lebih besar dari ketentuan signifikansi $p$-value $<0,05$. Dengan demikian dapat disimpulkan bahwa variabel penghimpunan zakat tidak berpengaruh terhadap produktivitas amil.

\subsubsection{Pengaruh Penghimpunan Infaq Terhadap Produktivitas Amil}

Amil bertugas menghimpun dana infaq/shodaqah baik individu maupun dari organisasi /perusahaan. Dalam menjalankan tugasnya, amil zakat dalam hal ini adalah para pengurus dan karyawan BAZNAS berhak mendapatkan hak amil biasanya sebesar $20 \%$ dari jumlah infaq/shodaqah yang dihimpun. Semakin besar dana infaq yang dihimpun maka semakin besar pula dana amil. Dana amil yang berasal dari $20 \%$ dari jumlah infaq/shodaqah dipakai oleh amil untuk mengelola infaq/shodaqah tersebut melalui penyaluran infaq/shodaqah sehingga dengan tugas tersebut dibutuhkan dana untuk membiayai operasional amil. Sehingga semakin besar dana infaq/shodaqah sangat mempengaruhi produktivitas amil. Namun berdasarkan hasil uji hipotesis statistik menunjukkan bahwa $p$-value pengaruh variabel penghimpunan infaq terhadap produktivitas amil sebesar 0,352 lebih besar dari ketentuan signifikansi $p$-value $<0,05$. Dengan demikian dapat disimpulkan bahwa variabel penghimpunan infaq tidak berpengaruh terhadap produktivitas amil.

\subsubsection{Pengaruh Produktivitas Amil Terhadap Kinerja Penyaluran}

Amil bertugas menyalurkan dana zakat kepada mustahik melalui kegiatan konsumtif, edukatif dan produktif. Beberapa organisasi pengelola zakat mampu menghimpun dana zakat dalam jumlah besar namun kurang mampu dalam menyalurkan dana zakat. Disisi lain, ada organisasi pengelola zakat kurang mampu menghimpun dana zakat dalam jumlah besar namun sangat mampu dalam menyalurkan dana zakat. Dibutuhkan manajemen Badan Amil Zakat yang kompeten, profesional sehingga mendorong produktivitas para pengurus dan karyawan mampu menghimpun dana zakat dalam jumlah besar sekaligus mampu 
dalam menyalurkan dana zakat. Sehingga semakin produktif amil zakat maka semakin baik kinerja penyaluran zakat. Namun berdasarkan hasil uji hipotesis statistik menunjukkan bahwa $p$-value pengaruh variabel produktivitas amil terhadap kinerja penyaluran zakat sebesar 0,183 lebih besar dari ketentuan signifikansi $p$ value $<0,05$. Dengan demikian dapat disimpulkan bahwa variabel produktivitas amil tidak berpengaruh terhadap kinerja penyaluran zakat.

\subsubsection{Pengaruh Produktivitas Amil Terhadap Kinerja Penyaluran Infaq}

Amil bertugas menyalurkan dana infaq/shodaqah kepada para dhuafa dan pihak yang sangat membutuhkan pertolongan melalui kegiatan konsumtif, edukatif dan produktif. Beberapa organisasi pengelola infaq/shodaqah mampu menghimpun dana infaq/shodaqah dalam jumlah besar namun kurang mampu dalam menyalurkan dana infaq/shodaqah. Disisi lain, ada organisasi pengelola infaq/shodaqah kurang mampu menghimpun dana infaq/shodaqah dalam jumlah besar namun sangat mampu dalam menyalurkan dana infaq/shodaqah Dibutuhkan manajemen Badan Amil Zakat yang kompeten, profesional sehingga mendorong produktivitas para pengurus dan karyawan mampu menghimpun dana infaq/shodaqah dalam jumlah besar sekaligus mampu dalam menyalurkan dana infaq/shodaqah. Sehingga semakin produktif amil maka semakin baik kinerja penyaluran infaq/shodaqah. Namun berdasarkan hasil uji hipotesis statistik menunjukkan bahwa p-value pengaruh variabel produktivitas amil terhadap kinerja penyaluran infaq/shodaqah sebesar 0,491 lebih besar dari ketentuan signifikansi $p$-value $<0,05$. Dengan demikian dapat disimpulkan bahwa variabel produktivitas amil tidak berpengaruh terhadap kinerja penyaluran infaq/shodaqah.

\section{KESIMPULAN DAN SARAN}

\subsection{Kesimpulan}

Berdasarkan hasil dan pembahasan penelitian yang telah di paparkan pada bab sebelumnya maka peneliti dapat menarik kesimpulan sebagai berikut:

1. Variabel penghimpunan zakat tidak berpengaruh terhadap produktivitas amil pada Badan Amil Zakat Nasional di Jawa Timur. Dapat disimpulkan bahwa hipotesis (H1) yang menyatakan bahwa penghimpunan zakat berpengaruh terhadap produktivitas amil ditolak.

2. Variabel penghimpunan infaq tidak berpengaruh terhadap terhadap produktivitas amil pada Badan Amil Zakat Nasional di Jawa Timur. Dapat disimpulkan bahwa hipotesis (H2) yang menyatakan bahwa penghimpunan infaq berpengaruh terhadap produktivitas amil ditolak.

3. Variabel produktivitas amil tidak berpengaruh terhadap kinerja penyaluran zakat pada Badan Amil Zakat Nasional di Jawa Timur. Dapat disimpulkan bahwa hipotesis (H3) yang menyatakan bahwa produktivitas amil berpengaruh terhadap kinerja penyaluran zakat ditolak.

4. Variabel produktivitas amil pada Badan Amil Zakat Nasional di Jawa Timur terhadap kinerja penyaluran infaq pada Badan Amil Zakat Nasional di Jawa Timur. Dapat disimpulkan bahwa hipotesis (H4) yang menyatakan bahwa produktivitas amil berpengaruh terhadap kinerja penyaluran infaq ditolak 


\subsection{Keterbatasan Penelitian}

Penelitian ini tidak dapat menghasilkan model penelitian yang sempurna karena disebabkan oleh beberapa terkait dengan keterbatasan penelitian, di antaranya yaitu;

1. Sampel penelitian ini sangat sedikit disebabkan karena masih banyak BAZNAS kabupaten di Jawa Timur yang belum memiliki laporan keuangan yang sesuai dengan PSAK 109

2. Variabel dalam penelitian sangat terbatas

\subsection{Saran}

Berdasarkan kesimpulan yang diperoleh dalam penelitian ini,dan keterbatasan yang terjadi selama penelitian maka diajukan saran sebagai sebagai berikut:

1. Manajemen BAZNAS kabupaten di Jawa Timur seharusnya dapat menyusun laporan keuangan yang sesuai dengan PSAK 109. Sehingga laporan keuangan tersebut bias dipakai oleh stakeholders untuk menilai kinerja BAZNAS dan sekaligus dapat dipakai para analis dan peneliti dalam melakukan analisis kinerja dan mengungkap persoalan dan menemukan faktor-faktor yang mempengaruhi kinerja BAZNAS kabupaten di Jawa Timur

2. Pada penelitian berikutnya diharapkan dapat menambah jumlah sampel penelitian dan memperluas wilayah sampel penelitian, bukan hanya di Jawa Timur saja tetapi membandingkan dengan antar Provinsi atau antar kabupaten dalam satu provinsi. Perluasan daerah survei bertujuan agar hasil penelitian selanjutnya lebih mungkin untuk disimpulkan secara menyeluruh atau umum.

\section{DAFTAR PUSTAKA}

Azizah, S. N. 2018. Efektivitas Kinerja Keuangan Badan Amil Zakat Nasional (Baznas) Pada Program Pentasharufan Dana Zakat Di Baznas Kota Yogyakarta. el-JIZYA Jurnal Ekonomi Islam 6 (1):91-112.

Devi, A. R. 2018. Pengaruh Profesionalisme, Job Stress, dan Perilaku Etis Terhadap Kinerja Karyawan pada Badan Amil Zakat Nasional (BAZNAS) di Jawa Timur. Skripsi, Program Studi Ekonomi Syariah. Fakultas Ekonomi dan Bisnis Islam, Universitas Islam Sunan Ampel Surabaya, Surabaya.

Gamal, M. Pengkajian Sosial Ekonimi Islam: Peran Syariah dalam Ekonomi. MES YAHOO.COM. Diakses pada 15 Januari 20192007 [cited.

Ghozali, I., dan H. Latan. 2015. Partial Least Square. Semarang: Universitas Diponegoro.

Harahap, S. S. 1997. Teori Akuntansi. PT Raja Grafindo Persada.

Keputusan Presiden RI No. 8 Tahun 2001 tentang Badan Amil Zakat Nasional.

Kustono, A. S., dan R. Effendi. 2016. Earnings Management and Corporate

Governance Case in Indonesia. Journal Advanced Science Letters 22 (12):4345-4347.

Lestari, A. 2015. Efisiensi Kinerja Keuangan Badan Amil Zakat Daerah (Bazda): Pendekatan Data Envelopment Analysis (DEA). Jurnal Ekonomi \& Studi Pembangunan 16 (2):117-187. 
Manan, M. A. 1986. Islamic Economics: Theory and Practice. Cambridge: Hodder and Strughton.

Mardani. 2015. Hukum Sistem Ekonomi Islam. Jakarta: Rajawali Pers.

Nurhayati, S., dan Wasilah. 2015. Akuntansi Syariah di Indonesia. Edisi 4 ed. Jakarta: Penerbit Salembe Empat.

Parisi, S. A. 2017. Tingkat Efisiensi dan Produktivitas Lembaga Zakat di Indonesia. Esensi: Jurnal Bisnis dan Manajemen 7 (1):63-72.

Putri, Y. H. 2017. Analisis Kinerja Pengelolaan Zakat di Badan Amil Zakat Nasional (BAZNAS) Kota Yogyakarta. Skripsi, Departemen Ekonomi Syariah. Fakultas Ekonomi dan Manajemen, Institut Pertanian Bogor, Bogor.

Sasongko, F. 2018. Analisis Efisiensi dan Efektifitas Kinerja Pengolahan Dana Zakat, Infaq, dan Shadaqah (ZIS): Studi pada 3 Organisasi Pengelola Zakat di Jawa Timur Periode 2014-2016, Universitas Islam Negeri Maulana Malik Ibrahim, Malang.

Sugiyono. 2016. Metode Penelitian Pendidikan. Bandung: CV. Alfabeta.

Triyuwono, I. 2006. Perspektif, Metodologi, dan Teori Akuntansi Syariah. Jakarta: PT. Raja Grafindo Persada.

Undang-Undang Nomor 23 Tahun 2011 tentang Pengelolaan Zakat. 